\title{
Pemahaman Nilai-Nilai Ketuhanan dan Sikap Solidaritas dengan Perilaku Jujur Siswa SMK PGRI I Kota Bogor
}

\author{
Muhamad Yusuf $^{1 *}$, Sri Rahayu Pudjiastuti ${ }^{2}$, Mohamad Sutisna ${ }^{2}$ \\ ${ }^{I}$ Ikatan Dokter Indonesia Cabang Bogor, Indonesia \\ ${ }^{2}$ STKIP Arrahmaniyah, Indonesia
}

\begin{abstract}
Abstrak-Nilai yang terkandung dalam Ketuhanan Yang Maha Esa manjadi sulit di realisasikan, terutama dalam mebangun kesadaran menghargai persamaan kedudukan warga negara, demikian juga dengan terwujudnya sikap solidaritas terhadap sesama siswa. Penelitian ini bertujuan untuk memperoleh data empiris mengenai Hubungan pemahaman Nilai-Nilai KetuhananYang Maha Esa dan Sikap Solidaritas dengan Perilaku Jujur siswa Kelas XII SMK PGRI I Kota Bogor. Penelitian ini dilaksanakan bulan Mei sampai Oktober 2019. Metode yang digunakan adalah metode deskriptif kuantitatif dengan studi koralasional. Jumlah sampel sebanyak 80 siswa yang di dapat Kata kunci:

Nilai-Nilai Ketuhanan, Solidaritas,

Perilaku Jujur. secara acak. Instrumen yang digunakan untuk variabel $\mathrm{X}_{1}$ (pemahaman Nilai-nilai Ketuhanan YME) dikur menggunakan tes dan $\mathrm{X}_{2}$ (sikap solidaritas) dan $\mathrm{Y}$ (perilaku jujur siswa) menggunakan angket skala perilaku. Pengujian hipotesis terbukti bahwa terdapat hubungan positif antara pemahaman nilai-nilai Ketuhanan Yang Maha Esa dan sikap solidaritas dengan perilaku jujur siswa. Koefisien korelasi jamak sebesar 0,993. Dari hasil perhitungan diperoleh koefisien determinasi sebesar 0,889. Dikatakan $88,9 \%$ variansi yang terjadi pada perilaku jujur siswa (Y) dapat dijelaskan oleh variabel pemahaman nilai-nilai Ketuhanan Yang Maha Esa $\left(\mathrm{X}_{1}\right)$ dan sikap solidaritas $\left(\mathrm{X}_{2}\right)$. Oleh karena itu dapat disimpulkan bahwa terdapat hubungan posistif antara pemahaman nilai-nilai Ketuhanan Yang Maha Esa dan sikap solidaritas dengan perilaku jujur siswa.

\author{
Histori: \\ Dikirim: 10 Maret 2021 \\ Direvisi: 15 Maret 2021 \\ Diterima: 17 Maret 2021 \\ Online: 18 Maret 2021
}

(C)2021 JCC. All rights reserved (c) (i) (2) Author(s) agree that this article remains permanently open access under the terms of the Creative Commons

Identitas Artikel:

Yusuf, M., Pudjiastuti, S. R., \& Sutisna, M. (2021). Pemahaman Nilai-Nilai Ketuhanan dan Sikap Solidaritas dengan Perilaku Jujur Siswa SMK PGRI I Kota Bogor. Jurnal Citizenship Virtues, 1(1), 63-68.
\end{abstract}

\section{PENDAHULUAN}

Generasi muda dalam hal ini secara umum adalah masa depan bangsa dan secara khusus para pemimpin bangsa di masa depan. Oleh karena para peserta didik adalah gambaran Indonesia di masa depan, maka implementasi nilai-nilai Ketuhanan kepada peserta didik menjadi sangat penting untuk diperhatikan. Sekurangkurangnya ada tiga argumrntasi mengapa implementasi nilai-nilai Pancasila penting

\footnotetext{
*Corresponding author

E-mail: rizkaoktavia0210@gmail.com
} 
bagi peserta didik. Pertama, nilai-nilai Ketuhanan Yang Maha Esa merupakan tulang punggung ilmu pengetahuan (Iriansyah, 2018). Lingkungan, baik keluarga maupun masyarakat ikut berperan dalam menciptakan kondisi peserta didik. Jika lingkungan baik, maka akan berpengaruh terhadap kondisi peserta didik. Kedua, untuk menciptakan kuatnya generasi muda ke depan perlu diciptakan struktur yang kuat berupa perangkat aturan dan kebijakan pendidikan yang menciptakan kondisi peserta didik. Ketiga, peserta didik adalah tunas-tunas bangsa yang merupakan generasi penerus masa depan. Masa depan yang penuh tantangan wajib dijawab oleh sumber daya manusia manusia yang berkualitas. Dalam hal ini, sebagai pendidik juga memiliki kewajiban untuk mendorong terciptanya kualitas manusia yang tidak saja berilmu pengetahuan tinggi tetapi juga memiliki karakter kebangsaan yang kuat (Pudjiastuti, 2020a).

Dalam Undang-undang Nomor 39 tahun 1999 dinyatakan bahwa manusia sebagai mahluk ciptaan Tuhan Yang Maha Esa mengemban tugas mengelola dan memelihara alam semesta dengan penuh ketaqwaan dan penuh tanggung jawab untuk kesejahteraan umat manusia oleh pencipta-Nya dianugerahi hak asasi untuk menjamin keberadaan harkat dan martabat kemuliaan dirinya serta keharmonisan lingkungannya. Pemahaman akan sila Ketuhanan Yang Maha Esa turut memberikan pemahaman kepada anak agar dapat menghormati kepentingan orang lain terutama dalam masalah beribadah kepada Yang Maha Kuasa serta membangun sebuah kedewasaan dalam bertindak, karenanya produk-produk kebijakan pembangunan yang kondusif mengeksklusifkan sekelompok penganut agama tidak mencerminkan nilai-nilai Ketuhanan. Hal ini disebabkan karena ekslusi berbasiskan agama bertentangan dengan nilai kesederajadan. Dan sikapsikap intoleransi terhadap warga Negara lain yang berbasis pada agama juga bertentangan dengan nilai tersebut.Sikap intoleransi ini telah menyalahi hak warga negara. Untuk terjaminnya perlindungan hak-hak warga negara, maka diperlukanlah sikap solidaritas (Mappapoleonro, 2018). Kerangka untuk menumbuh kembangkan sikap solidaritas, diperlukan sikap sebagai berikut: (1) menjauhkan sikap fanatik yang berlebihan, yaitu sikap yang tidak menghargai suku, ras dan pemeluk agama lain bahkan memusuhinya; (2) tidak mencampuradukan ajaran agama satu dengan ajaran agama yang lainnya, toleransi beragama tidak berarti mencampuradukan ajaran agama; (3) menjauhi sikap acuh tak acuh terhadap agama dan kepercayaan lain (Wahab, 1993).

Keselarasan kehidupan umat beragama yang pluralistik di Indonesia tidak harus dipertentangkan, karena ,masalah keyakinan merupakan salah satu hak asasi manusia, diperlukan suatu sikap demokrasi untuk saling menghormati agar terwujud kondisi kehidupan beragama yang serasi, selaras dan seimbang di tiap tingkatan social masyarakat Indonesia, untuk kemudian bermuara bagi terwujudnya kerukunan dan persatuan bangsa (Fatimah, 2020). Nilai yang terkandung dalam Ketuhanan Yang Maha Esa manjadi sulit di realisasikan, terutama dalam mebangun kesadaran menghargai persamaan kedudukan warga negara, demikian juga dengan terwujudnya sikap solidaritas terhadap sesama siswa. Siswa lebih banyak mementingkan diri dan kelompoknya sendiri tanpa memperdulikan siswa dan kelompok lainya. Kondisi ini jelas bertentangan dengan konsep yang terkandung dalam nilai Ketuhanan Yang Maha Esa dan pelaksanaan sikap solidaritas. Sesuai dengan realitas dan sistem pergaulan siswa, membutuhkan perilaku jujur bagi para siswa (Adlan, 2009). 
Dalam suatu survey penelitian yang dilakukan oleh Profesor Donald L.Mc.Cabe di Graduate Scool of Management Rutgers University (1995); Ketidakjujuran akademik meresap dengan melakukan kecurangan pada karya tulis (plagiarisme) $58 \%$, dengan melakukan pemalsuan kepustakaan, memalsukan pekerjaan yang dilakukan orang lain atau dengan sengaja tidak melakukan catatan kaki atau mencatat kutipan dari sumber (Solikah \& Waluyo, 2018). Tingginya tingkat kecurangan juga ditemukan oleh kelompok Who's Who Among Americant High School Students (2015), yang mendapatkan pada survei bahwa di dapat tingkat kecurangan hampir 90\%, dengan pernyataan siswa bahwa kecurangan adalah "umum disekolah" (76\%). Dalam tulisannya, Wasesa \& Diana (2016) bahwa ada siswa menggunakan internet untuk memperoleh keuntungan dalam melakukan perilaku kecurangan, dengan menggunakan sebagai fitur, fungsi pencarian, penerjemah bahasa asing, mengirim program dan lainnya. Alasan dominan karena siswa menganggap kecurangan dalam internet sebagai alternatif yang dapat diterima untuk melakukan pekerjaan atau tugas-tugas mereka. Ironisnya bila ada teman yang tidak mau membantu melakukan kecurangan tersebut dianggap tidak solider.

Solidaritas yang tidak pada tempatnya menjadi dilema di persekolahan. Satu sisi guru mengajarkan kejujuran, keyakinan akan adanya nilai Ketuhanan Yang Maha Esa, tapi fakta di lapangan para siswa berada pada pilihan tidak memiliki sikap solidaritas bila tidak membantu teman, termasuk membantu perbuatan curang dengan memberikan contekan saat ujian, membuat makalah hanya dikerjakan oleh orang tertentu saja, yang lain hanya mencantumkan nama saja, demikian juga dengan tugas-tugas lainnya, karenanya Pudjiastuti (2020a) menjelaskan implementasi nilai-nilai Pancasila bagi generasi milenial yang terintegrasi dalam kurikulum pendidikan dengan menekankan aspek praktek, tidak kognitif semata, mengikutsertakan semua stakeholder yang ada. Mengenalkan kearifan lokal mulai dari cerita rakyat, kesenian tradisional, hingga permainan tradisional. Selanjutnya Pudjiastuti (2020b) juga menjelaskan bahwa cara yang dapat dilakukan untuk menginternalisasikan nilai-nilai luhur Pancasila adalah; memperkuat sistem pendidikan, meningkatkan identitas diri dan karakter bangsa, pemimpin nasional memiliki komitmen yang tinggi, mengimplementasikan nilai-nilai Pancasila dalam kehidupan nyata agar memiliki kemampuan untuk menangkal pengaruh negatif.

\section{METODE PENELITIAN}

Metode penelitian yang digunakan adalah metude kuantitatif dengan pendekatan korelasional. Kuntitatif Karena data yang diperlukan untuk menganalisis hubungn antar variabel tersebut berbentuk angka (data numerik) hasil pengukuran dengan menggunakan metode uji statistik.Tujuan penelitian korelasi adalah untuk mengetahui bagaimana hubungan antar dua atau lebih variabel baik pola, arah, sifat dan bentuk, maupun kekuatan hubungannya karenanya disebut juga sebagai penelitian korelasional (Pudjiastuti, 2017). Penelitian ini dilakukan pada siswa di Kelas XII SMK PGRI I Kota Bogor sejumlah 958 orang, sedangkan populasi terjangkau sebanyak 270 orang berada di 8 kelas. Sampel penelitian ini ditetapkan 80 orang, dipilih berdasarkan simple random sampling. Uji coba instrumen diambil sebanyak 30 orang yang tidak termasuk sampel dengan cara yang sama. 
Instrumen yang dipakai untuk mengukur variabel pemahaman nilai-nilai Ketuhanan Yang Maha Esa menggunakan tes, untuk variable sikap solidaritas menggunakan angket skala sikap, sedangkan variabel perilaku jujur menggunakan angket skala perilaku. Keseluruhan instrument telah diuji coba tingkat validitas dan reliabilitasnya pada taraf signifikansi 0,05 . Pengujian hipotesis dilakukan dengan korelasi Product Moment. Untuk menguji hipotesis penelitian digunakan teknik analisa varians, setelah sebelumnya dilakukan uji persyaratan analisis yaitu uji normalitas dengan liliefors, dan homogenitas varians dengan uji Bartlet (Pudjiastuti, 2019).

\section{HASIL DAN PEMBAHASAN}

Berdasarkan analisis data dengan menggunakan teknik korelasional, diperoleh hasil pengujian hipotesis pertama yang menunjukkan bahwa pemahaman nilai-nilai Ketuhanan Yang Maha Esa memiliki hubungan positif dan sangat signifikan dengan perilaku jujur. Kadar hubungan antara pemahaman nilai-nilai Ketuhanan Yang Maha Esa dengan perilaku jujur ditunjukkan oleh korelasi $r_{y 1}=0,727$ sangat signifikan di mana. Hasil penelitian ini memberikan informasi bahwa seorang siswa akan berperilaku jujur jika memiliki pemahaman nilai-nilai Ketuhanan Yang Maha Esa yang memadai. Hal ini menunjukkan bahwa makin tinggi pemahaman nilainilai Ketuhanan Yang Maha Esa maka makin tinggi pula perilaku jujur siswa tersebut. Sebaliknya makin rendah pemahaman nilai-nilai Ketuhanan Yang Maha Esa maka makin rendah pula perilaku jujur siswa tersebut. Hasil penelitian menunjukkan bahwa koefisien determinasi sebesar 0,491 memberikan pengertian bahwa 49,1\% variansi perubahan perilaku jujur ditentukan oleh pemahaman nilainilai Ketuhanan Yang Maha Esa. Berdasarkan hasil penelitian tersebut menunjukkan bahwa pemahaman nilai-nilai Ketuhanan Yang Maha Esa mempunyai kontribusi bagi perilaku jujur.

Hasil pengujian hipotesis kedua menunjukkan bahwa sikap solidaritas memiliki hubungan positif dan sangat signifikan dengan perilaku jujur. Kadar hubungan antara sikap solidaritas dengan perilaku jujur ditunjukkan oleh korelasi $r_{y 2}=0,665$ sangat signifikan. Hasil penelitian ini memberikan informasi bahwa agar seorang siswa berperilaku jujur dan hendaknya memiliki sikap solidaritas. Hal ini menunjukkan bahwa makin tinggi sikap solidaritas maka makin tinggi perilaku jujur siswa tersebut. Sebaliknya makin rendah sikap solidaritasnya maka makin rendah pula perilaku jujur siswa tersebut. Hasil penelitian menunjukkan bahwa koefisien determinasi sebesar $(0,665)^{2}=0,418$ memberikan pengertian bahwa $41,8 \%$ variansi perubahan perilaku jujur oleh sikap solidaritas. Berdasarkan hasil penelitian tersebut menunjukkan bahwa sikap solidaritas mempunyai kontribusi bagi perilaku jujur siswa.

Hasil pengujian hipotesis ketiga menunjukkan bahwa pemahaman nilai-nilai Ketuhanan Yang Maha Esa dan sikap solidaritas secara bersama-sama memiliki hubungan positif dan sangat signifikan dengan perilaku jujur. Keeratan hubungan tersebut ditunjukkan oleh koefisien korelasi jamak $r_{y .12}=0,993$ sangat signifikan. Koefisien determinasi sebesar 0,889 menunjukkan bahwa 88,9\% variansi perilaku jujur ditentukan secara bersama-sama oleh pemahaman nilai-nilai Ketuhanan Yang Maha Esa dan sikap solidaritas. Sumbangan kedua variabel tersebut sebesar 88,9\% kepada perilaku jujur, menunjukkan bahwa perilaku jujur masih ditentukan oleh 
faktor lain, misalnya kesdarannya, komitmen, tanggung jawab, budaya, konsep diri, faktor lingkungan dan lain-lain. Berdasarkan hasil analisis ini, maka dapat memberikan peluang kepada peneliti lain untuk mengadakan penelitian tentang perilaku jujur dan faktor-faktor lain yang mempengaruhinya.

\section{KESIMPULAN}

Hasil pengujian hipotesis menunjukkan bahwa ketiga hipotesis yang diajukan dalam penelitian ini diterima dengan signifikan. Dengan demikian, dari hasil penelitian diperoleh sejumlah penemuan dan kesimpulan sebagai berikut:

Pengujian hipotesis pertama menyimpulkan bahwa terdapat hubungan positif antara pemahaman nilai-nilai Ketuhanan Yang Maha Esa dengan perilaku jujur. Koefisien determinasi adalah $r_{y 1}{ }^{2}=(0,727)^{2}=0,491$ atau $49,1 \%$. Hal ini berarti bahwa 49,1\% variansi perilaku jujur (Y) dapat dijelaskan oleh variabel pemahaman nilainilai Ketuhanan Yang Maha Esa $\left(\mathrm{X}_{1}\right)$. Oleh karena itu temuan penelitian ini menunjukkan bahwa makin tinggi pemahaman nilai-nilai Ketuhanan Yang Maha Esa maka makin tinggi pula perilaku jujur. Sebaliknya makin rendah pemahaman nilai-nilai Ketuhanan Yang Maha Esa maka makin rendah pula perilaku jujur. Berdasarkan temuan ini dapat dijelaskan bahwa untuk meningkatkan perilaku jujur dapat dilakukan dengan meningkatkan pemahaman nilai-nilai Ketuhanan Yang Maha Esa.

Pengujian hipotesis kedua membuktikan bahwa terdapat hubungan positif antara sikap solidaritas dengan perilaku jujur. Koefisien korelasi antara variabel, yakni hubungan antara sikap solidaritas $\left(\mathrm{X}_{2}\right)$ dengan perilaku jujur (Y) $r_{y 2}=(0,665)^{2}=0,418$. Hal ini berarti bahwa $41,8 \%$ variansi perilaku jujur $(\mathrm{Y})$ dapat dijelaskan oleh variabel sikap solidaritas $\left(\mathrm{X}_{2}\right)$ sehingga terdapat hubungan positif antara sikap solidaritas dengan perilaku jujur. Oleh karena itu temuan penelitian ini menunjukkan bahwa makin tinggi sikap solidaritas, maka makin tinggi pula perilaku jujur. Sebaliknya makin rendah sikap solidaritas maka makin rendah pula perilaku jujur siswa.

Penemuan hipotesis ketiga, terbukti terdapat hubungan positif antara pemahaman nilai-nilai Ketuhanan Yang Maha Esa dan sikap solidaritas dengan perilaku jujur. Koefisien korelasi jamak sebesar 0,993. Dari hasil perhitungan diperoleh koefisien determinasi sebesar 0,889. Dikatakan 88,9\% variansi yang terjadi pada perilaku jujur (Y) dapat dijelaskan oleh variabel pemahaman nilai-nilai Ketuhanan Yang Maha Esa $\left(\mathrm{X}_{1}\right)$ dan sikap solidaritas $\left(\mathrm{X}_{2}\right)$. Oleh karena itu dapat dikatakan bahwa terdapat hubungan posistif antara pemahaman nilai-nilai Ketuhanan Yang Maha Esa dan sikap solidaritas dengan perilaku jujur. Temuan ini dapat diartikan bahwa makin tinggi pemahaman nilai-nilai Ketuhanan Yang Maha Esa serta makin baik sikap solidaritas, maka makin tinggi pula perilaku jujur siswa. Hal ini menunjukkan pentingnya kedua variabel tersebut untuk meningkatkan perilaku jujur siswa.

Berdasar ketiga penemuan dalam penelitian tersebut di atas, maka dapat disimpulkan bahwa perilaku jujur terbukti dapat ditingkatkan bila pemahaman nilai-nilai Ketuhanan Yang Maha Esa tinggi dan sikap solidaritasnya baik, apakah secara sendiri-sendiri maupun secara bersama-sama. 


\section{REFERENSI}

Adlan, A. (2009). Fenomena Hilangnya Kejujuran. Jakarta: Restu Illahi.

Fatimah, S. H. (2020). Peningkatan Pemahaman Siswa Tentang Keberagaman Suku, Ras, Agama Dalam Bingkai Bhineka Tunggal Ika Dan Demokrasi Melalui Strategi Pembelajaran Student Teams Achievement Division. Sintesa: Jurnal Ilmu Pendidikan, 15(1), 37-44.

Iriansyah, H. S. (2018). Manajemen Strategi Pengamanan Wilayah Nasional dalam Prespektif Geopolitik dan Geostrategi Perbatasan NKRI. Jurnal Ilmu Pendidikan (JIP) STKIP Kusuma Negara, 9(2), 1-16.

Mappapoleonro, A. M. (2018). Pola Pemanfaatan Ruang Rumah Susun dalam Bermain Anak Usia Dini: Penelitian Kualitatif di RT 08 RW 10 Kompl PU Pasar Jumat Pondok Pinang. Jurnal Ilmu Pendidikan (JIP) STKIP Kusuma Negara, 10(1), 85-99.

Pudjiastuti, S. R. (2017). Metode Penelitian Pendidikan. Depok: Fatma Aji.

Pudjiastuti, S. R. (2019). Penelitian Pendidikan. Yogyakarta: Media Akademi.

Pudjiastuti, S. R. (2020a). Implementasi Nilai-Nilai Pancasila bagi Generasi Milenial. In Tim Asosiasi Dosen Pancasila dan Kewarganegaraan (Eds.). Implementasi Nilai-Nila Pancasila Di Era 4.0, pp. 65-88. Depok: Gemala.

Pudjiastuti, S. R. (2020b). Internalisasi Nilai-Nilai Pancasila Dalam Mencegah Paham Radikal. Jurnal Ilmiah Mimbar Demokrasi, 19(2), 32-39.

Solikah, S. N., \& Waluyo, S. J. (2018). Hubungan Persepsi Pemahaman Mahasiswa tentang Pendidikan Anti Korupsi dengan Hasil Belajar Mahasiswa Keperawatan. Proceeding of The URECOL, 558-565.

Wahab, A. A. (1993). Materi Pokok Pendidikan Pancasila. Jakarta: Universitas Terbuka.

Wasesa, A. F., \& Diana, R. R. (2016). Pengaruh Pelatihan Rasional Emotif Perilaku terhadap Penurunan Perilaku Kecurangan Akademik Siswa. JIP (Jurnal Intervensi Psikologi), 8(1), 41-52. 